\title{
Characterization of chemical and mineral composition of marolo (Annona crassiflora Mart) during physiological development
}

\author{
Edson Pablo da SILVA ${ }^{1}$, Wilson Cesar de ABREU ${ }^{2}$, Otávio Alteff GONÇALVES ${ }^{1}$, Clarissa DAMIANI ${ }^{1}$, \\ Eduardo Valério de Barros VILAS BOAS²
}

\begin{abstract}
Maroleiro (Annona crassiflora Mart), belonging to the family of Annonaceae is a typical specie of the Cerrado and has occurred in most states. For fruit characteristics "sui generis", with significant nutritional value. This study aimed to characterize the marolo (Anonna crasiflora Mart) during fruit development, through the evaluation of its proximal and mineral composition. The fruits 2012/2013 season, were picked to $12 \mathrm{Km}$ from the city of Itumirim, southern Minas Gerais, in intervals of 20 days from anthesis to maturity, and the first fruits were harvested 60 days after anthesis. The flowering marolo began in late September 2012, with fruiting initially observed at the end of October, with peak production at the end of February and beginning of March 2013 The fruits were harvested in the morning and carried to the laboratory, where followed up the moisture, ether extract, protein, ash, fiber and high sugar fraction beyond mineral quantification of them. During development reductions in moisture content and protein increments of ether extract, crude fiber and high sugar fraction and an oscillation in the mineral along the developmental stages was observed.
\end{abstract}

Keywords: nutritional value; savannah fruits; mineral content; chemical fruits.

Practical Application: Development of new food products with high added value has become a challenge for food industry, since the nutritional quality of the same, will depend on the raw material used. Thus, the knowledge of news raw material rich in bioactive compounds and high nutritional content is essential in the obtainment of new food products with a good source of nutrients with great importance in the daily alimentation, contributing in the preservation of savannah fruits.

\section{Introduction}

Nutritional and commercial potential knowledge of the native species could be an economic alternative to the livelihood of native population from different regions (Silva et al., 2013). Fruits and vegetables are important examples of essential elements source. Minerals perform a specific function in human development and fruits are considering the mainly mineral sources which are required in the human diet (Hardisson et al., 2001). Therefore, the Cerrado biome constitutes a large natural source of biological resources, fauna and flora, occupying approximately $22 \%$ of the whole country, which about $90 \%$ are located in the states of São Paulo, Minas Gerais, Mato Grosso, Goiás e Bahia.

This biome is considerate the second largest in the country, behind of the amazon forest (Silva et al., 2001). Preservation of your biodiversity and traditional agricultural systems, become a crucial objective aimed on environmental protection and sustainability, as well the leveraging of the global bio-economy. It is estimated that there are 5000-7000 plant species in the Cerrado biodiversity, which $40 \%$ are woody.

Among which, protrude several examples of different families which produces edible fruits, with different shapes, attractive colors and characteristic flavor, already being sold at trade fairs with great popular acceptance. Although, noticed a crescent increase in studies with native fruits as well the development of new food products based on them, the information about the nutritional potential of the cerrado's fruits are limited or, often, do not exist, occurring a lack on scientific investments in this area (Souza et al., 2012).

These fruits are a source of functional compounds with beneficial healthy properties, which might stimulate their use by the pharmaceutical and food industries for the development of new products, promoting the sustainability development of the regions with cerrado's characteristics (Siqueira et al., 2013). Nowdays, there are more than 58 species of natives fruits known and used by the population (Ávidos \& Ferreira, 2005). Predominant flora is composed of $42 \%$ of native plants, $48 \%$ of species coming from other vegetation types and $10 \%$ of species which occur in more than one type of formation (Rizzini, 1971), becoming an inexhaustible source of nutrition resources, and may occur essentials nutrients for the human metabolism such as vitamins and minerals.

The concentration of nutrients in fruits is directly related to their physiological age, and depends mainly on their stage 
of development and supply of nutrients in the soil. Minerals are indispensable nutritious substances for the organism, because promote since the bones constitution, teeth, muscles, blood, and nervous cells until the water balance. They are as important as the vitamins to assist the organism in perfect health. Though, since the organism cannot produce them, we must need an external source, as the food and if necessary, the nutritious supplements to ensure an adequate intake. After their incorporation in the organism, the minerals do not remain static, being transported throughout the body and eliminated by the excretion (Food Ingredients Brasil, 2008).

The recommended daily intake (IDR) and the quantity of fats, glycine, vitamins, minerals, and proteins which must be taken daily to attend the nutritional necessity of the most part of the individuals and group of peoples of a healthy population (Brasil, 1998).

On this context the study about cerrado's fruits become important, due the knowledge of the minerals composition, these come to occupy a prominent position as regards fruits with a huge nutritional values, which also assists the preservations of specimens. Among these, the maroleiro or araticum (A. crassiflora Mart) is a typical fruit of Cerrados, Cerradões, Dense Cerrado, Drain cerrado and rupestrian fields. Belonging to Anonaeae's family, is appreciate by the aroma and flavor of their fruits. With the desire of divulge the nutritional potentialities of marolo and to study the evolution of the mineral content during their development, this research aimed the study of the proximal and minerals compositions of marolo (A. crassiflora Mart) of the southern region of Minas Gerais during their development.

\section{Materials and methods}

\subsection{Obtaining the fruits and installation of experiment}

This research was initially conducted at a native pasture area with a typical cerrado formation under oxisol red, localized $12 \mathrm{~km}$ from Itumirim city, southern state of Minas Gerais.

They were selected at random, 33 examples of Annona crassiflora Mart species, which were marked the flower open during the anthesis, with wool yarn of different colors, in different position in the plant. The fruits (harvest 2012/2013) were harvested at intervals of twenty days, as of the $60^{\circ}$ day of their formation, following until the plant abscission. The fruits were harvest during the morning, packed in polyethylene bags in low density and transported to the Laboratory of Postharvest of Fruits and Vegetables, Department of Food Science.

\section{Experimental delineation}

The experiment was conducted in a simple delineation fully randomized consists of six collection points $(60,80,100,120$, 140 and 145 days) with four replications containing three fruits.

\section{Sample preparation}

After the fruits collecting, these were taken to the laboratory, where they were washed and sanitized. A portion of the pulp was removed for the determination of the subsequent analyzes.

\section{Determination of proximal composition}

The determination of humidity, ether extracts, proteins, fibers and ashes, were determined according to the methodology described by Association of Official Agricultiral Chemists (2010).

\section{Glycidic fraction}

It was calculated the glycidic fraction by the difference of the second equation: \%G.F. $=100-(\%$ humidity $+\%$ ether extract $+\%$ crude protein + crude fiber $+\%$ ash fractions), considering the entire material.

\section{Analysis of the mineral elements contents}

The sample preparation occurred by the nitric-perchloric digestion, was weighed $0.5 \mathrm{~g}$ of the sample in digestion tube, adding $6 \mathrm{~mL}$ of a mixture of $\mathrm{HNO} 3$ and HCLO4 in the ratio 2:1 $(\mathrm{v} / \mathrm{v})$, and taken to the digester block, gradually increasing the temperature until reaching a temperature of $210^{\circ} \mathrm{C}$, presenting the colorless extract. For the determination of calcium, copper, iron, sodium, potassium, magnesium, and phosphorus, it was used an atomic absorption spectrophotometer flame (SpectrAA 110, Varian), calibrated in specific conditions of wavelength, slit, and mixing of the gases for each element. To construct the calibration curve, standards vials were used for Merck atomic absorption properly diluted with deionized water. Analyses were performed in triplicate (Andrade et al., 2000).

\section{Statistical analysis}

Statistical analysis of the chemical and physical variables was performed with the support of SISVAR program (Ferreira, 2010). After the analysis of variances of the results, it was noticed the significance level of the test $F$. The average of the evaluation periods (weeks) were submitted to polynomial regression, where models were selected according to the significance of the test $\mathrm{F}$ of each model and with the determination coefficient.

\section{Results and discussions}

The study of proximal composition and mineral content during the fruit development was marked by significant elevation in their levels, notably changes observed from the 120th day of development. This development period was marked by significant elevation and decreases in those variables. Results obtained on this experiment about determination of marolo's proximal compositions during the development can be observed in the Figure 1. During the period of studies, which had as a start point a fruit with 60 days after anthesis and the end point with 145 days, was detected reduction on humidity contents (Figure 1a), which might have been provided by ambient weather conditions during the development, by loss of water at physiological process, as well by cell wall synthesis which raise levels of dry matter and decreases the percentage of humidity in the fruit. According with Taiz \& Zeiger (2002), during the physiological process of fruits, might occur significant changes on their nutritional compounds, as well the loss of water at respiratory process. Similar results were observed by Morzelle et al. (2015), for curriola 70.68\% and murici $70.90 \%$. Higher values were detected by Almeida 

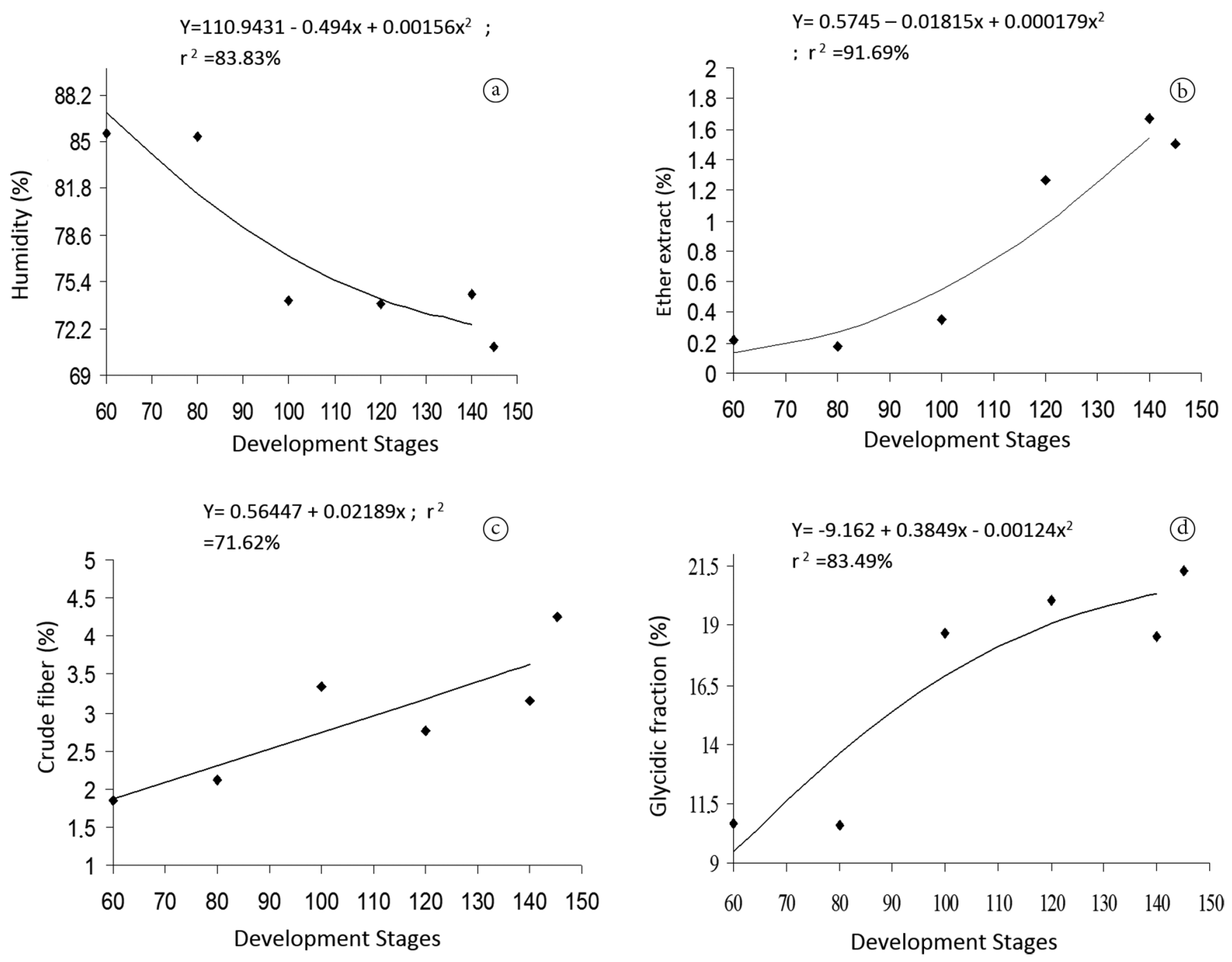

Figure 1. Adjusted average values and regression equations for humidity variables (a); ether extract (b); crude fiber (c); glicidic fraction (d); in full substance during the development of marolo. (Annona crassiflora Mart).

(1998), when working with mature marolo fruits $(76.32 \%)$ and Silva et al. (2009) for gabiroba $77.02 \%$.

Increments in ether extract content from $0.2 \%$ to $1.6 \%$ (Figure 1b), crude fiber from $1.8 \%$ to $4.0 \%$ (Figure 1c), and glycidic fractions from $11.2 \%$ to $21.3 \%$ (Figure 1d), also observed during the fruits' developments. Most transformations on the proximal compositions were observed from the $100^{\text {th }}$ day. Point which was detected decrease in humidity contents, which might have influence the concentrations of these within the fruit, also associate to synthesis process. Also was observed, on this period, the higher concentrations of protein and ashes, followed by decline and stability presenting at the end of development, protein value $1.7 \%$, higher value than soursop (1.1\%) (Universidade Estadual de Campinas, 2011) and 1.07\% for ashes, however, this variation observed for protein and ash content not showed significant difference $(\mathrm{p}<0.05)$. This variation on protein contents might be due consumption of them on metabolic process as enzyme activity. Damiani et al. (2011), founded protein and lipid levels encountered were 1.87 g. $100 \mathrm{~g}^{-1}$ (pulp) and $1.39 \mathrm{~g} .100 \mathrm{~g}^{-1}$ (skin) and 0.33 g. $100 \mathrm{~g}^{-1}$ (pulp) and $0.32 \mathrm{~g} .100 \mathrm{~g}^{-1}$ (skin), respectively. These values differed from those found by Caldeira et al. (2004) - $10 \%$ proteins and $1.02 \%$ lipids, but they were similar to those observed by Franco (2004) when analyzing white guava protein contents $\left(1.09 \mathrm{~g} .100 \mathrm{~g}^{-1}\right)$ and araça lipid contents $\left(0.2 \mathrm{~g} .100 \mathrm{~g}^{-1}\right)$. Reduction on ashes values might be related to climate variations and availability of minerals on soil during the fruit development. Protein intake should be 10 to 15 grams/day (Franco, 2004).

In general, foods are mainly source of minerals to organism, both vegetables and animals origin. On these foods, the mineral is in the form of natural organic complex, which can already be used by organism. However, not always are enough about quality and quantity to satisfy the organism necessity and it is necessary resort to mineral supplements (Food Ingredients Brasil, 2008). Availability of nutrients in soil is closely linked to the percentage of minerals found in the analyzed fruit. Concentration of nutrients in is closely linked with this availability in soil, 
and might pledge direct effect in proteins content because they are part of amino acids (Espindula et al., 2010). It was noticed during the marolo's development, oscillations on minerals content (Figure 2), which can elucidate the detected variation on ashes values during development. Was observed, on calcium content (Figure 2a), a decrement on their values during the development. This oscillations on calcium, copper (Figure 2b), and iron contents might be associate with the availability of them in soil, which directly influences the absorption of these nutrients by the plant. Pavinato \& Rosolem (2008) relate that the availability of nutrients in soil directly influences on their absorption by the plants.

(a)
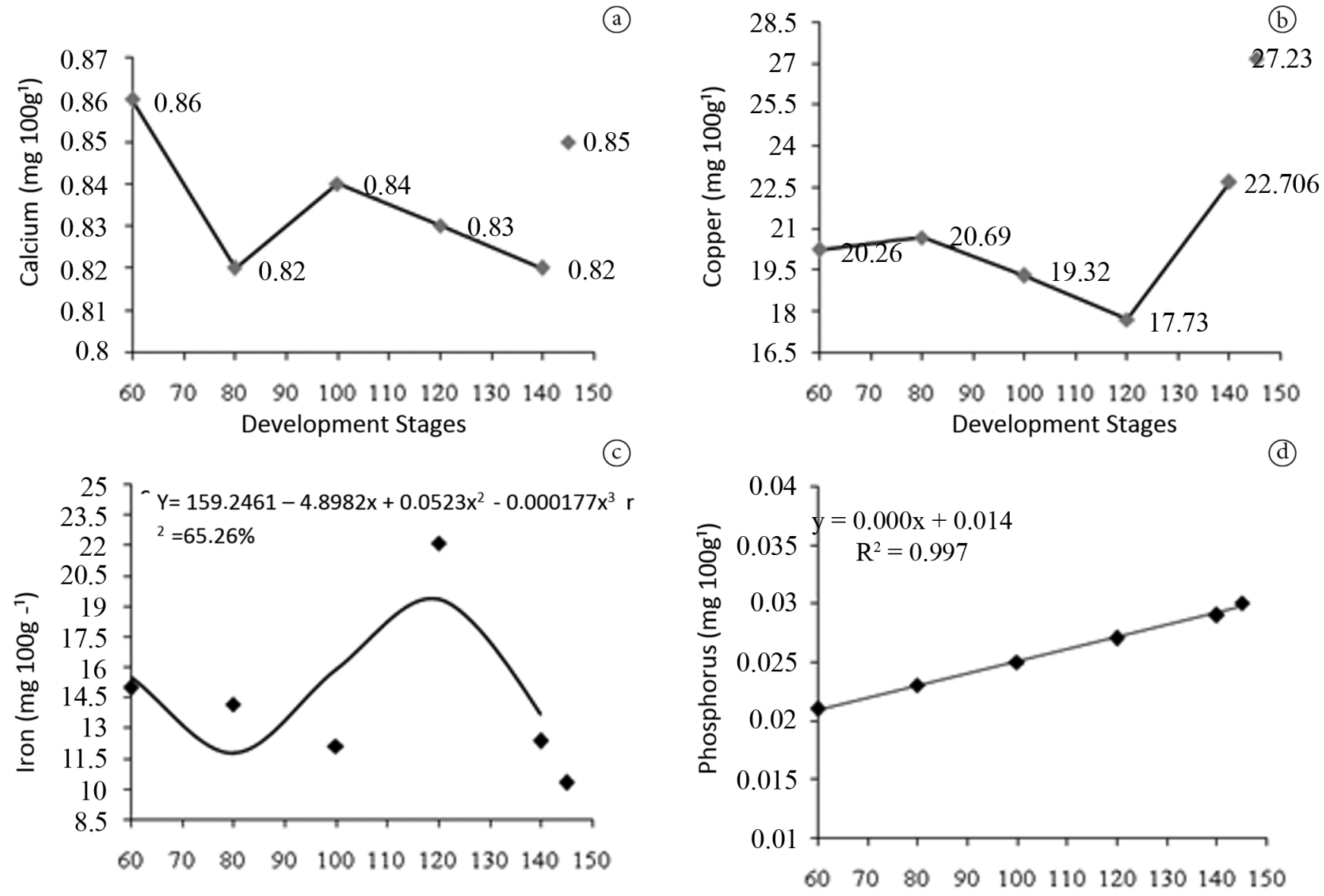

Development Stages

Development Stages

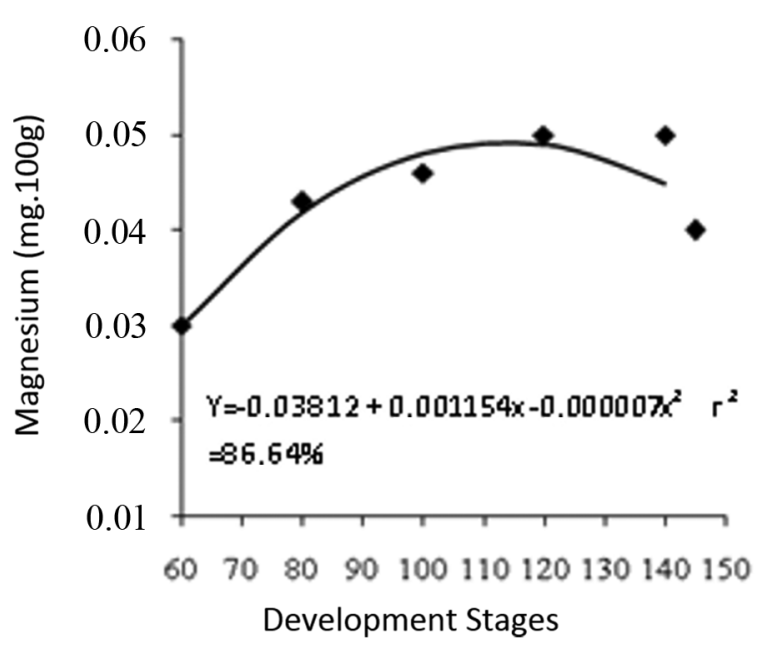

(e)

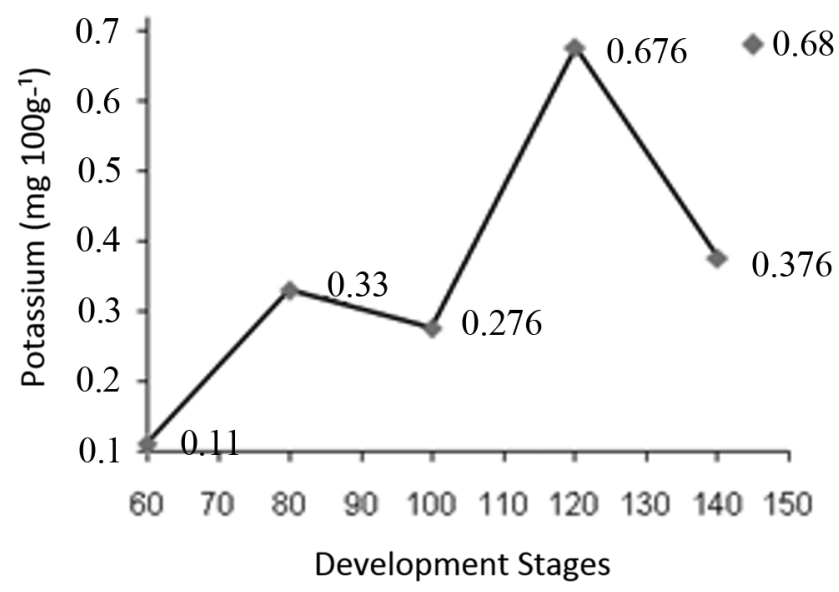

Figure 2. Adjusted average values and regression equations for the variables of calcium (a); Copper (b); Iron (c); phosphorus (d); magnesium (e) and potassium (f) for the development of marolo (Annona crassiflora Mart). 
Decrease in calcium and iron levels, it may be related to the mineral characteristics of cerrado soil, which can directly affect the content of the plant, influenced by inadequate balance. In the food sector, the calcium exerts an essential function in combating osteoporosis, which today affects mainly women. According Universidade Estadual de Campinas (2011) the daily recommendation of calcium for individuals between 19-50 years is around of $1000 \mathrm{mg}$. Copper might operate as a good antioxidant besides being components of several enzymes involved on cell energy production. The daily recommendation required for this mineral is $2-5 \mathrm{mg}$ /day. The iron is indispensable for the correct development of several physiological functions. Among them, the iron might be involved on activation of several enzymes such as catalase, which ensures the degradation of free radicals. Iron $(\mathrm{Fe})$ is a micro-element and one of the most frequently cited as important minerals in food. According to Franco (2004), two conventional greenery, watercress and spinach are an important source, having utilization of $68 \%$ by organism. Although, according to Rogez (2000), absorption of vegetables' iron by men is only $5 \%$, which is found mainly in free form. Among the native species, a little quantity or almost nothing is known about the content, and even less on chemical form and bioavailability, requiring more detailed studies. Noticed during the marolo's development, increase on iron content until the 120th day, reaching the decrease on it content after this period. This event might be related with their utility in several biochemical processes of fruit, since it might be involved in several enzymatic reactions. For phosphorus contents (Figure 2d) and magnesium (Figure 2e), was detected a slight increment on their contents during the development period of fruits, which phosphorus and magnesium amounts respectively observed were $0.021 \%$ and $0.03 \%$ at 60 th day of development $0.0031 \%$ and $0.04 \%$. The phosphorus has structural role in cell notably in phospholipids and is a constituent of cell membranes. The daily intake of this mineral is approximately $4 \mathrm{mcg} /$ day (Universidade Estadual de Campinas, 2011). It is noteworthy that the values found in marolo not make up the required daily amount of this nutrient.

The magnesium is involved in enzyme regulation in organism, intervening in the duplication of nucleic acids in neural excitability and nerve impulse transmission, acting on the ion exchange of membrane cell. The indication of daily consumption between 19 and 30 years is $400 \mathrm{mg}$, after 30 years this recommendation goes to 420mg / day. (Universidade Estadual de Campinas, 2011; Food Ingredients Brasil, 2008). Potassium (Figure 2e) obtained an increment on it content within the development of fruit, reaching $0.68 \%$ at 145 th development day. Gondim et al. (2005) and Aquino et al. (2014), observed higher values than those found in this research when they studied the proximate composition and minerals on fruits peels. Kinupp \& Barros (2008) found similar values and lower than those found on this experiment, studying the protein and mineral contents of several native species.

\section{Conclusion}

Decrease in moisture content observed throughout the development positively influenced the data obtained for the proximal composition. The marolo constitutes as a good mineral source and presenting higher levels of phosphorus and magnesium. Other minerals evaluated suffer oscillations throughout the development, probably influenced by the availability in the soil.

\section{References}

Almeida, S. P. (1998). Frutas nativas do cerrado: caracterização físicoquímica e fonte potencial de nutrientes. In S. P. Almeida. Cerrado: ambiente e flora (pp. 247-281). Planaltina: Embrapa-CPAC.

Andrade, M. S., Silva, C. F., Carvalho, M. S., \& Santos, C. D. (2000). Metodologia para análise foliar elementos em material vegetal (11 p.). Lavras: Universidade Federal de Lavras.

Association of Official Agricultiral Chemists - AOAC. (2010). Official methods of the Association of the Agricultural Chemists (1094 p.). Washington, DC: AOAC.

Aquino, C. F., Salomao, L. C., Siqueira, D. L., Cecon, P. R., \& Ribeiro, S. M. R. (2014). Teores de minerais em polpas e cascas de frutos de cultivares de bananeira. Pesquisa Agropecuária Brasileira, Brasilia, 49(7), 546-553. http://dx.doi.org/10.1590/S0100-204X2014000700007.

Ávidos, M. F. D., \& Ferreira, L. T. (2005). Frutos do Cerrado: preservação gera muitos frutos. Retrieved from http://www.biotecnologia.com. br/bio15/frutos.pdf.

Brasil. (1998, January 13). Portaria MS n 33, de 13 de janeiro de 1998. Ingestão Diária Recomendada (IDR) para proteínas, vitaminas e minerais. Diário Oficial [da] República Federativa do Brasil. Retrieved from http://e-legis.anvisa.gov.br/leisref/public/showAct. php? id=18828\&word $=$.

Caldeira, S. D., Hiane, P. A., \& Ramos, M. I. L. (2004). Caracterização físico-quimica do araça (psidium guineense Sw.) e do tarumã (Vitex cymosa Bert.) do Estado do Mato Grosso do Sul. Boletim CEPPA, 22(1), 145-154.

Damiani, C., Vilas Boas, E. V. B., Asquieri, E. R., Lage, M. E., Oliveira, R. A., Silva, F. A., Pinto, D. M., Rodrigues, L. J., Silva, E. P., \& Paula, N. R. F. (2011). Characterization of fruits from the savanna: Araça (Psidium guinnensis Sw.) and Marolo (Annona crassiflora Mart.). Ciencia \& Tecnologia de Alimentos., 31(3), 723-729. http://dx.doi. org/10.1590/S0101-20612011000300026.

Espindula, M. C., Campanjhar, M., Rocha, V. S., Monerrat, P. H., \& Favarato, L. F. (2010). Composição mineral de grãos de trigo submetidos a doses de sulfato de amônio e trinexapac-etil. Pesquisa Agropecuária Tropical ia, 40(4), 513-520. http://dx.doi.org/10.1590/ S1983-40632010000400014.

Ferreira, D. F. (2010). Sisvar: sistema de análise de variância. Versão 5.3. Lavras: UFLA.

Food Ingredients Brasil. (2008, No. 4). Retrieved from www.revista-fi.com.

Franco, G. (2004). Tabela de composição química dos alimentos (9th ed., 307 p.). São Paulo: Atheneu.

Gondim, J. A. M., Moura, M. de F.V., Dantas, A. S., Medeiros, R. L. S., \& Santos, S. M. (2005). Composição centesimal e de minerais em cascas de frutas. Ciência e Tecnologia de Alimentos, 25(4), 825-827. http://dx.doi.org/10.1590/S0101-20612005000400032.

Hardisson, A., Rubio, C., Baez, A., Martin, M., Alvarez, R., \& Diaz, E. (2001). Mineral composition of the banana (Musa acuminata) from the island of Tenerife. Food Chemistry, 73(2), 153-161. http:// dx.doi.org/10.1016/S0308-8146(00)00252-1.

Kinupp, V. F., \& Barros, I. B. I. (2008). Teores de proteína e minerais de espécies nativas, potenciais hortaliças e frutas. Ciência e Tecnologia de Alimentos, Campinas, 28(4), 846-857. http://dx.doi.org/10.1590/ S0101-20612008000400013. 
Morzelle, M. C., Bachiega, P., Souza, E. C., Vilas Boas, E. V. B., \& Lamounier, M. L. (2015). Caracterizaçao química e física de frutos de curriola, gabiroba e murici provenientes do Cerrado brasileiro. Revista Brasileira de Fruticultura, 37(1), 96-103. http://dx.doi. org/10.1590/0100-2945-036/14.

Pavinato, P. S., Rosolem, C. A. (2008). Disponibilidade de nutrientes no solo: decomposição e liberação de compostos orgânicos de resíduos vegetais. Revista Brasileira de Ciências do Solo, 32(3). Retrieved from http://www.scielo.br/scielo.php?script=sci_arttex t\&pid=S0100-06832008000300001

Rizzini, C. T. (1971). Aspectos ecológicos da regeneração em algumas plantas do cerrado. In Anais do $3^{\circ}$ Simposio sobre o Cerrado, São Paulo, Brasil.

Rogez, H. (2000). Açaí: preparo composição e melhoramento da conservação (313 p.). Belém: EDUFPA.

Silva, E. P., Vilas Boas, E. V. B., Rodrigues, L. J., \& Siqueira, H. H. (2009). Caracterização física, química e fisiológica de gabiroba (Campomanesia pubescens) durante o desenvolvimento. Ciência e Tecnologia de Alimentos, 29(4), 803-809. http://dx.doi.org/10.1590/ S0101-20612009000400016.
Silva, E. P., Vilas Boas, E. V. B., \& Xisto, A. L. P. (2013). Characterization and development of marolo (Annona crassiflora, Mart.). Ciência e Tecnologia de Alimentos, 33(4), 1-10.

Silva, D. B., Silva, J. A., Junqueira, N. T. V., \& Andrade, L. R. M. (2001). Frutas do Cerrado (178 p.). Brasília: Embrapa Informação Tecnológica.

Siqueira, E. M. de A., Rosa, F. R., Fustnoni, A. M., Sant'Ana, L. P., \& Arruda, S. F. (2013). Brazilian savanna fruits contain higher bioactive compounds content and higher antioxidant activity relative to the conventional red delicious apple. PLoS One, 8(8), 1-7. http://dx.doi. org/10.1371/journal.pone.0072826.

Souza, P. M., Elias, S. T., Imenoni, L. A., Paula, J. E., Gomes, S. M., Guerra, E. N. S., Fonseca, Y. M., Silva, E. C., Silveira, D., \& Magalhaes, P. O. (2012). Plants from Brazilian cerrado with potent tyrosinase inhibitory activity. Plos One, 7(11), 1-7.

Taiz, L., \& Zeiger, E. (2002). Plant physiology (3rd ed., 395 p.). Sunderland: Sinauer Associates.

Universidade Estadual de Campinas - UNICAMP. (2011). Tabela Brasileira de Composição de Alimentos - TACO (4th ed.). Campinas: UNICAMP/NEPA. 